\title{
Determining the maximum surface temperature for non-electrical equipment aiming at explosion prevention at protection
}

\author{
Adrian Marius Jurca*, Niculina Vătavu, Leonard Lupu, and Mihai Popa \\ ${ }^{1}$ National Institute for Research and Development in Mine Safety and Protection to Explosion - \\ INSEMEX, 32-34 G-ral Vasile Milea street, 332047, Petrosani, Hunedoara county, Romania
}

\begin{abstract}
Non-electrical equipment has been used for over 150 years in industries with potentially explosive atmospheres and great experience has been gained with regard to the application of protective measures to reduce the risk of ignition down to an acceptable safety level. The use of nonelectrical equipment in explosive atmospheres required the development of specific requirements with regard to the concept of protection against the ignition of explosive atmospheres, which to clearly define protection measures and to include the experience gained and extended over the years. The practical studies, laboratory research and methods for assessing and testing the hazard of ignition by hot surfaces presented within the paper have as main purpose the improvement of ignition hazard assessment in different operating conditions.
\end{abstract}

\section{Introduction}

Checks must be carried out when using equipment and component in dangerous places to see if the risks of ignition can happen, taking into account the ignition processes. The fire risks must be taken to eliminate ignition sources to the dangerous place if there is the probability of occurrence. If this is not available, extra protective measures should be implemented to ensure an adequate protection level $[1,2]$.

The measures implemented must make the ignition sources harmless or limit the probability of the ignition sources to occurring. This can be achieved through adequate equipment and component design and construction, operating procedures and adequate measurement and control systems as well.

Protective measurement relies on the possibility of an explosive atmosphere occurring and the effects of possible explosions. In this sense the classification of non-electrical equipment is achieved through a difference between different categories of equipment, as specified in Directive 2014/34/EU - ATEx. These categories reflect the requirements for different areas and hazard conditions [3-5].

The non-electrical equipment's for potentially explosive atmospheres are classified in groups and categories - see the table 1.

\footnotetext{
* Corresponding author: adrian.jurca@insemex.ro
} 


\section{Ignition hazard assessment of non-electrical equipment}

Equipment that has been designed and constructed according to the applicable safety requirements of relevant industrial standards, and where the ignition hazard assessment confirms that the equipment does not contain any effective ignition sources in normal operation, can be classified as EPL Gc or Dc.

Where the ignition hazard assessment confirms that the equipment does not contain any effective ignition sources during normal operation and expected malfunctions, the equipment can be classified as EPL $\mathrm{Mb}, \mathrm{Gb}$ or $\mathrm{Db}$.

Where the ignition hazard assessment confirms that the equipment does not contain any effective ignition sources during normal operation, expected malfunctions and rare malfunctions, the equipment can be classified as EPL Ma, Ga or Da.

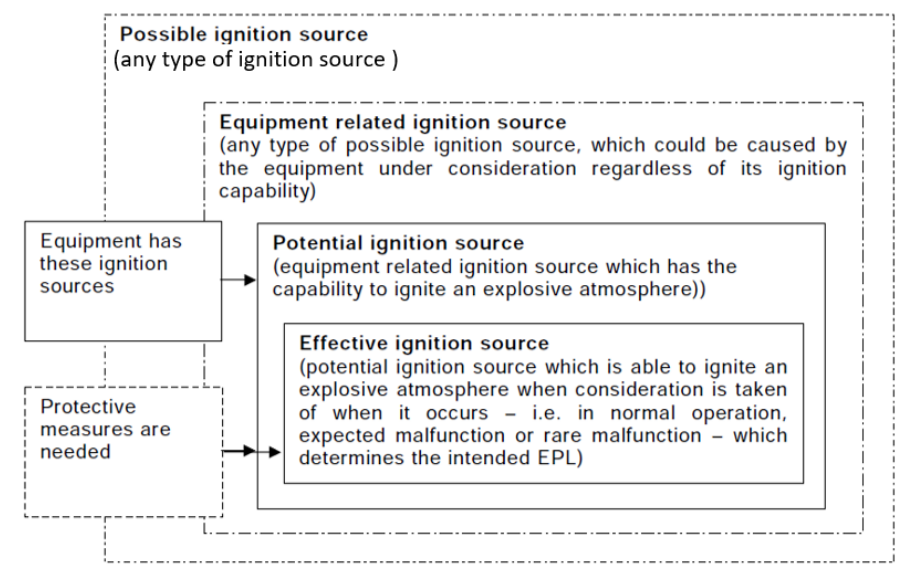

Fig. 1. Relation between ignition source definitions

When using equipment under dangerous circumstances, it is necessary to check whether ignition risks can arise, considering the mechanisms of ignition. The equipment must be subjected to a formal documented ignition hazard assessment to identify all potential ignition sources that could occur during normal operation, expected malfunction and rare malfunction. Then, depending on the intended EPL (Equipment Protection Level) of the equipment, mitigation can be applied to each of these potential ignition sources to minimize the likelihood that they could become effective ignition sources [6].

Table 1. Relation between Equipment protection levels (EPLs) and zones

\begin{tabular}{|c|c|c|c|c|}
\hline \multicolumn{2}{|c|}{ SR EN ISO 80079-36 } & \multicolumn{2}{|c|}{$\begin{array}{l}\text { Directive } 2014 / 34 / \mathrm{UE} \\
\text { ( GD no. } 245 / 2016 \text { ) }\end{array}$} & $\begin{array}{l}\text { SR EN 60079-10-1 } \\
\text { SR EN 60079-10-2 }\end{array}$ \\
\hline EPL & Group & $\begin{array}{l}\text { Equipment } \\
\text { Group }\end{array}$ & $\begin{array}{l}\text { Equipment } \\
\text { Category }\end{array}$ & Zones \\
\hline $\mathrm{Ma}$ & \multirow{2}{*}{ I } & \multirow{2}{*}{ I } & M1 & \multirow{2}{*}{ Not Applicable } \\
\hline $\mathrm{Mb}$ & & & M2 & \\
\hline $\mathrm{Ga}$ & \multirow{3}{*}{ II } & \multirow{6}{*}{ II } & $1 \mathrm{G}$ & 0 \\
\hline $\mathrm{Gb}$ & & & $2 \mathrm{G}$ & 1 \\
\hline $\mathrm{Gc}$ & & & $3 \mathrm{G}$ & 2 \\
\hline $\mathrm{Da}$ & \multirow{3}{*}{ III } & & $1 \mathrm{D}$ & 20 \\
\hline $\mathrm{Db}$ & & & $2 \mathrm{D}$ & 21 \\
\hline Dc & & & $3 \mathrm{D}$ & 22 \\
\hline
\end{tabular}


The formalised process shall be applied to cover design, construction, installations, inspection, testing and maintenance requirements for the protective functions.

Protective measures or types of protection shall be considered or applied in the following order:

-minimize the likelihood that ignition sources arise;

-minimize the likelihood that ignition sources become effective;

-minimize the likelihood of the explosive atmosphere reaching the ignition source;

-contain the explosion and minimize the likelihood of flame propagation.

In the following table are presented the sources of ignition that can be generated by the non-electrical equipment.

Table 2. Assessment of non-electric equipment related ignition sources

\begin{tabular}{|c|c|c|}
\hline Possible Ignition Sources & $\begin{array}{c}\text { Equipment Related } \\
\text { Yes/No }\end{array}$ & Reason \\
\hline Hot surfaces & Yes & $\begin{array}{c}\text { Inside and outside - Gas compression, } \\
\text { vane friction, particle ingress }\end{array}$ \\
\hline Mechanical sparks & Yes & Particles could produce hot-spots \\
\hline Flames, hot gases & $\begin{array}{c}\text { Outside No } \\
\text { Inside Yes }\end{array}$ & $\begin{array}{c}\text { Inside compression temperature to be } \\
\text { measured - gas temperature directly at } \\
\text { exhaust }\end{array}$ \\
\hline Electrical sparks & No & Not present \\
\hline $\begin{array}{c}\text { Stray electric currents } \\
\text { and cathodic corrosion protection }\end{array}$ & No & Not present \\
\hline Static electricity & Yes & Vanes, lipseal, exhaust filter, float \\
valve
\end{tabular}

\subsection{Hot surfaces}

When using equipment and components in hazardous conditions, must be made checks to see whether ignition hazards may occur, taking into account the ignition processes. The measures shall be made the ignition sources harmless or shall be reduce the likelihood of occurrence of effective ignition sources. This may be achieved through an adequate design and construction of equipment and components, by operating procedures and also by adequate measuring and control systems.

If a hot surface is in contact with an explosive atmosphere, the ignition can result. Not only a hot surface or mechanical spark can be an ignition sources, but a layer of combustible dust that comes in contact with a hot surface and it is ignited by the hot surface, can be considered an ignition source for an air-gas or air-combustible dust mixture.

If the hazards generated by the hot surfaces have been identified, the specific requirement for the equipment must be fulfilled depending on the explosive atmosphere, group/category and operating mode (normal operation, malfunction, expected malfunction).

The ability of a heated surface to cause ignition depends upon the type and concentration of the specific substance in air mixture. This ability increases with the temperature rise and surface area increase. Moreover, the temperature that triggers ignition depends upon the size and shape of the heated body, on the gradient of the concentration in 
the surface's surrounding area and, in a certain amount, on the surface's material. On the other hand, in case of hot bodies with convex surfaces, compared to the ones having concave surfaces, in order to obtain ignition a much higher surface temperature is required for example, in case of spheres or pipes, the minimum ignition temperature increase with decreasing the diameter value. When an explosive atmosphere is leaking along hot surfaces, due to the short time of being in contact, a much higher surface temperature could be required $[5,7,8]$

Besides the easily recognizable hot surfaces, as dryers and others, the equipment's moving parts may also generate dangerous temperatures. These processes include also equipment which transforms mechanical energy into heat. Additionally, all mobile parts in bearings, etc. may become ignition sources if not properly lubricated. It should also be taken into account the temperature rises due to chemical reactions (for example with lubricants and/or cleaning agents) [8].

The research and tests carried out have highlighted the factors that can influence the results of the measurements in order to establish own risk assessment procedures. Also, the results of the research carried out can be useful in the revision and development of safety regulations and standards.

\section{Determining the maximum surface temperatures to the non- electrical equipment - vertical pump with progressive cavity}

The maximum surface temperature shall be determinate in the most adverse conditions according with the destination of the equipment and the category. The temperature of the highest point in contact with explosive atmosphere that would result in the highest surface temperature should be determined [4].

The paper presents a laboratory test having in view the determination of the maximum surface temperature developed by a vertical pump with progressive cavities designed transportation of oil and leakages on oil and gas parks. In case of this equipment - vertical pump with progressive cavity PB.60.12 type, the maximum surface temperature was determinated with thermo-vision integrated system (laptop - thermo-vision camera software for data processing and interpreting) in normal operating conditions and in expected malfunctions. The thermal image system allows accurate measurement of the heating phenomena generated by the moving part, of the phenomena with fast evolution, which results improve the assessment process of the ignition source.

The research carried out has led to the development of procedures for assessing the maximum risk, by simulating the most accurate factors which can influence the final results (identification of the mechanisms leading to the generation of hot surfaces, simulation of possible defects, air flow, lubricants, etc.) as well as by using efficient and state-of-theart equipment for identifying the hottest points / areas on the surface of the tested equipment.

The tests were carried out to the nominal parameters defined by the manufacturer, maximum flow of $60 \mathrm{~m}^{3} / \mathrm{h}$ and maximum pressure of $12 \mathrm{bar}$ and the temperature of the reticulated liquid was $50^{\circ} \mathrm{C}$.

The following components of the type PB 60.12 vertical pump had been identified and the maximum surface temperatures for these determined for the two functioning regimes normal operation and expected malfunctions:
a) drive belts;
b) transmission module
c) mechanical seal/slide ring seal
d) stator-rotor assembly 
Table 3. Measured value of the maximum temperature

\begin{tabular}{|c|c|c|}
\hline $\begin{array}{c}\text { Components of the } \\
\text { vertical pump PB 60.12 type }\end{array}$ & \multicolumn{2}{|c|}{$\begin{array}{c}\text { The measured value of the } \\
\text { maximum surface temperature }\end{array}$} \\
\cline { 2 - 3 } & in normal operation & in expected malfunction \\
\hline drive belts & $35.5^{\circ} \mathrm{C}$ & $\begin{array}{c}102.5^{\circ} \mathrm{C} \\
\text { (incorrect belts tension) }\end{array}$ \\
\hline $\begin{array}{c}\text { transmission module } \\
\text { upper bearing }\end{array}$ & $40^{\circ} \mathrm{C}$ & $\begin{array}{c}73.5^{\circ} \mathrm{C} \\
\text { (insufficient vaseline) }\end{array}$ \\
\hline $\begin{array}{c}\text { transmission module } \\
\text { lower bearing }\end{array}$ & $55^{\circ} \mathrm{C}$ & $\begin{array}{c}68.5^{\circ} \mathrm{C} \\
\text { (insufficient vaseline) }\end{array}$ \\
\hline mechanical seal/slide ring seal & $50.5^{\circ} \mathrm{C}$ & $\begin{array}{c}62.5^{\circ} \mathrm{C} \\
\text { (insufficient vaseline) }\end{array}$ \\
\hline stator-rotor assembly & $66.8^{\circ} \mathrm{C}$ & $\begin{array}{c}67.6{ }^{\circ} \mathrm{C} \\
\text { (outworn assembly) }\end{array}$ \\
\hline
\end{tabular}

Analyzing the results, the value of the maximum temperature for the critical components of the vertical pump in the most adverse conditions according with the destination, result the highest surface temperature.
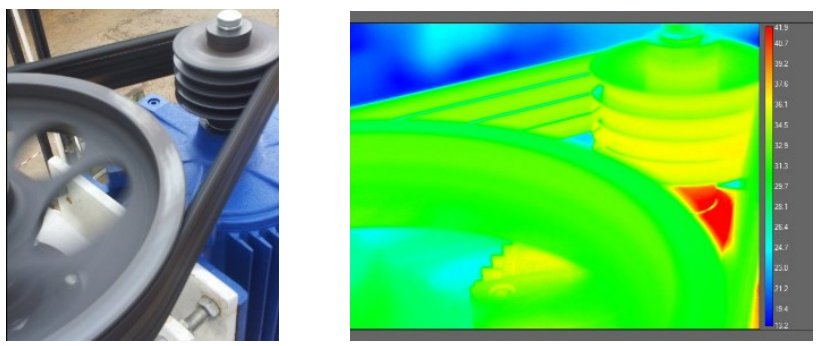

The measured value of the maximum surface temperature in normal operation was $35,5^{\circ} \mathrm{C}$

Fig. 2 - Determination of the maximum surface temperature - drive belts - normal operation
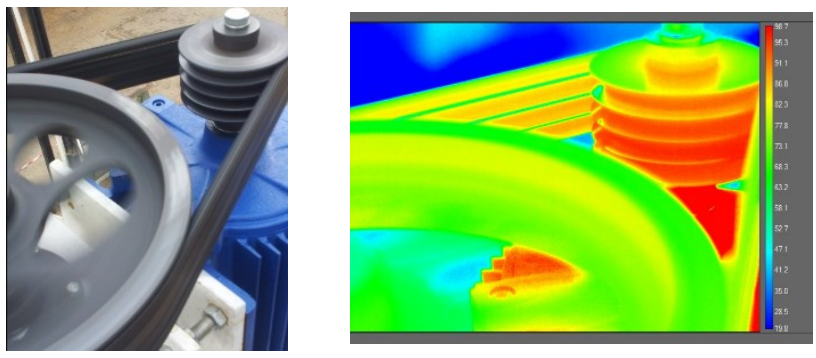

In this case, expected malfunction, the maximum surface temperature was $102,5^{\circ} \mathrm{C}$

Fig. 3 - Determination of the maximum surface temperature - drive belts - expected malfunction incorrect belts tension

Table 4. Classification of maximum surface temperatures for Group II equipment

\begin{tabular}{|c|c|}
\hline $\begin{array}{c}\text { Temperature } \\
\text { class }\end{array}$ & $\begin{array}{c}\text { Maximum surface temperature } \\
{ }^{\circ} \mathbf{C}\end{array}$ \\
\hline $\mathrm{T} 1$ & $\leq 450$ \\
\hline $\mathrm{T} 2$ & $\leq 300$ \\
\hline $\mathrm{T} 3$ & $\leq 200$ \\
\hline $\mathrm{T} 4$ & $\leq 135$ \\
\hline $\mathrm{T} 5$ & $\leq 100$ \\
\hline $\mathrm{T} 6$ & $\leq 85$ \\
\hline
\end{tabular}


As part of the ignition hazard assessment, the maximum surface temperature of the equipment shall be established. Having in view the maximum surface temperature of the equipment, and the classification of the maximum surface temperature for group II equipment - see table 4 , the manufacturer can define the temperature class of the vertical pump, in this case is - T4 $\left(\leq 135^{\circ} \mathrm{C}\right)$.

\section{Conclusions}

The use of non-electrical equipment in explosive atmospheres required the development of specific requirements with regard to the concept of protection against the ignition of explosive atmospheres, which to clearly define protection measures and to include the experience gained and extended over the years.

The practical studies, laboratory research and methods for assessing and testing the hazard of ignition by hot surfaces presented within the paper have as main purpose the improvement of ignition hazard assessment. If the hazards generated by the hot surfaces have been identified, the specific requirement for the equipment must be fulfilled depending on the explosive atmosphere, group/category and operating mode (normal operation, malfunction, expected malfunction).

The procedure of ignition risk assessment for the design of equipment and components leads to a defined safety level that allows categorization according to the appropriate criteria.

\section{References}

1. M. Părăian, G.A. Găman, C. Lupu, E. Ghicioi, S.Burian, N. Vătavu, J. Ionescu, A.Jurca, M.Friedmann, F.A.Păun, M. Magyari, L. Lupu, L. Moldovan, F. Muntean Berzan, T.Csaszar, N. Vlasin, M. Darie, (2014), Guidelines for evaluation of systems and personal protective equipment on the risk of explosions in environments with potentially explosive atmospheres (in Romanian), INSEMEX Publisher, Petrosani, Romania

2. D. Pasculescu, L. Pana, V. M. Pasculescu, F. Deliu, Mining of Mineral Deposits, 13 (2), 1-16, (2019)

3. V. M. Pasculescu, S. M. Radu, E. Ghicioi, D. Pasculescu, T. Niculescu, Proceedings of the 14th International Multidisciplinary Scientific GeoConference SGEM 2014, 1 (2), 43-50, (2014)

4. Directive 2014/34/UE

5. A. Jurca, M. Paraian, N. Vatavu, F. Paun, L. Lupu - Proceedings of the 17th International Multidisciplinary Scientific GeoConference SGEM 2017, 17, (2017).

6. Jurca A., Optimization of the assessment methods of the mechanical equipment regarding the ignition of the potentially explosive atmosphere by hot surfaces, Nucleu Programme (PN 07-4502-60) National Institute for Research and Development in Mine Safety and Protection to Explosion INCD INSEMEX Petroșani (2015)

7. Standard SR EN ISO 80079-36(2016)

8. Standard SR EN ISO 80079-37(2016) 